\title{
Aa. Vv., «Revue des Deux Mondes»
}

\section{Lise Sabourin}

\section{(2) OpenEdition}

\section{Journals}

\section{Édition électronique}

URL : http://journals.openedition.org/studifrancesi/34817

DOI : 10.4000/studifrancesi.34817

ISSN : 2427-5856

\section{Éditeur}

Rosenberg \& Sellier

\section{Édition imprimée}

Date de publication : 1 novembre 2005

Pagination : 427-428

ISSN : 0039-2944

\section{Référence électronique}

Lise Sabourin, « Aa. VV., «Revue des Deux Mondes»», Studi Francesi [En ligne], 146 (XLIX | II) | 2005,

mis en ligne le 30 novembre 2015, consulté le 19 avril 2021. URL : http://journals.openedition.org/ studifrancesi/34817 ; DOI : https://doi.org/10.4000/studifrancesi.34817

\section{Ce document a été généré automatiquement le 19 avril 2021.}

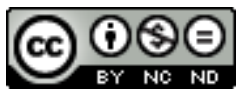

Studi Francesi è distribuita con Licenza Creative Commons Attribuzione - Non commerciale - Non opere derivate 4.0 Internazionale. 


\title{
Aa. Vv., «Revue des Deux Mondes»
}

\author{
Lise Sabourin
}

\section{RÉFÉRENCE}

AA. VV., «Revue des Deux Mondes», juillet-août 2003, n 7-8, pp. 192.

1 Cette livraison de la revue née en 1829 comporte trois articles intéressants pour les dixneuviémistes: deux sur Stendhal, un sur Saint-René Taillandier.

2 René SERVOISE (pp. 36-39) rappelle les liens entre La Chartreuse de Parme et Le Guépard (1958) de Giuseppe Tomasi, prince de Lampedusa, dont la bibliothèque ne comportait pas moins de 11000 livres français, auteur de Lezioni su Stendhal (traduites en français par Maurice Darmon Nadeau 1985) et d'un Stendhal (traduit par Monique Bacceli Allia, 2002). Puis André Zavriew (pp. 40-47) relate le voyage en Inde (1828-1832) de son «jumeau intellectuel» (selon l'expression de Miche1 Crouzet), Victor Jacquemont. Ca1cutta, Bénarès, Delhi, Bombay, Himalaya tibétain, Pendjab, Cachemire: l'Inde anglaise comme l'indépendante ont beaucoup apporté au naturaliste du Muséum, ont fourni aussi la matière d'une correspondance publiée dès 1833 à ce "causeur charmant», décédé du choléra au terme de sa mission, qui pourrait "être à la fois un double et un héros» (p. 41) de Stendhal.

LUC FRAISSE (pp. 11-28), après son ouvrage, Les Fondements de l'histoire littéraire, de SaintRené Taillandier à Lanson (Champion, 2002), démontre, à travers les relations entre Buloz et l'universitaire son ami, comment la «Revue des deux mondes» a pu infléchir l'histoire de la critique en ce $\mathrm{XIX}^{\mathrm{e}}$ siècle qui opère «une répétition générale de notre temps» tout en fonctionnant sur d'autres «rouages institutionnels» (p. 12). Le siège de la revue, 18-20 rue Saint-Benoît de 1846 à 1867, est situé chez le père de Saint-René Taillandier, collaborateur dès 1842, toujours fidèle lors de la crise du journal en 1870. Il y apporte, aux côtés de Quinet, autre spécialiste, toute sa connaissance de la littérature allemande. Mais, en ce temps où écrivains et critiques, professeurs et hommes politiques, historiens et philosophes travaillent coude à coude (Musset, Sainte-Beuve, Cousin, Guizot, Villemain, Mignet, Michelet Thierry...) le directeur de presse suggère 
aussi des méthodes promises à grand avenir universitaire: tableaux d'histoire littéraire (par groupes et familles d'écrivains), périodisation (du bilan par décennie à l'annuaire tous azimuts), bibliographie (et même bibliométrie). Ainsi la «Revue» participe-t-elle activement, par un refus relativiste de tout dogmatisme, au renouveau de la critique du présent et à l'histoire littéraire du passé, s'écartant de la docte rhétorique in abstracto héritée du XXVIII siècle (genre et style des œuvres) pour appréhender in vivo la littérature comme «une histoire vivante des moeurs» (p. 22), ainsi que l'avait conseillé Mme de Staël dès De l'Allemagne. 